\title{
Interactions of intracellular mediators of amylase secretion in permeabilized pancreatic acini
}

\author{
Motoji Kitagawa, John A. Williams and Robert C. De Lisle \\ Department is Phisiologi: Unuersin of Mtchigun. Ann Arhor. MIIU.S.A.) \\ (Received 27 April 1990) \\ (Revised manuscript received 10 September 1990|
}

K.y woids: Anylase secretion. Permeability; Calcium ion effect: (Mouse f-ancreatic acinar cell)

Mousc pancreatic acini were permeabilized with streptolysin 0 to investigate amylase secretion stimulated by various intracellular mediators and the kinetics of secretion as a function of temperature. Amylase secretion was temperature dependent in that the initial rate of $\mathrm{Ca}^{2+}$-stimulated secretion increased with increasing temperature. In addition, there was no enhancement of $\mathrm{Ca}^{2+}$-stimulated secretion by $\mathrm{GTP}|\gamma \mathrm{S}|$ at $14^{\circ} \mathrm{C}$, while enhancement was maximal at $30^{\circ} \mathrm{C}$. GTPI $\gamma \mathrm{S} \mid$-mediated enhancement of secretion at a given t:mperature was mostly due to sustained secretion with a small increase in secretory rate. At $30^{\circ} \mathrm{C} \mathrm{Ca}^{2+}$-stimulated secreticn was also enhanced by cAMP and phorbol ester (TPA) to similar extents as by GTP| $\gamma \mathrm{S}$ ]. The maximally effective concen'ration of $\mathrm{cAMP}$ was $1-10 \mu \mathrm{M}$ in the presence of 0.1 $\mathrm{mM}$ isobutylmethylxanthine. The enhancements of $\mathrm{Ca}^{2+}$-stimul sted amylase secretion by all combinations of cAMP $(100 \mu \mathrm{M}$ plus $0.1 \mathrm{mM}$ isobutylmethylxanthine), TPA $(1 \mu \mathrm{M})$, and $\mathrm{GTP} \mid \gamma \mathrm{S}](30 \mu \mathrm{M})$ were fully additive. In $\mathrm{Ca}^{2+}{ }_{-}$free

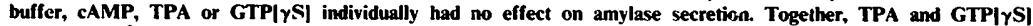
stimulated $\mathrm{Ca}^{2+}$-independent se'retion, which was $187 \pm 38 \%$ of basal. Cyclic AMP together with TPA and GTPIyS| in the absence of $\mathrm{Ca}^{2+}$ stimulated $329 \pm 30 \%$ of basal secretion. $\mathrm{Ca}^{2+}$-stimulated amylase secretion was decreased about $50 \%$ by metabolic inhibition, while the enhancement by cAMP, TPA or GTP|rS| was totally blocked by metabolic inhibitors. These data demonstrate that amylase secretion in the acinar cell is mediated by multiple intracellular pathways which act in parallel and probably converge at a distal step in the exocytotic process.

\section{Introduction}

Pancreatic exocrire secretion is stimulated by the gut hormones cholecystokinin (CCK) and secretin and by the neurotransmitters acetylcholine ( $\mathrm{ACh}$ ) and vasoactive intestinal polyreotide (VIP). CCK and ACh act by stimulating phosphutidylinositol 4.5-bisphosphate breakrlown to produce diacylglycerol (DAG) and inositol 1,4,5-trisphosphate $\left(\mathrm{IP}_{3}\right)$, with subsequent activation of protein kinase $\mathrm{C}$ (by DAG) and calcium mobilization (by $\left.I_{3}\right)[1]$. VIP and secretin activate adenylate cyclase to produce cAMP witis subsequent activation of

Abbreviations: CCK. cholecystokinin: ACh, acetylcholine: VIP. vasoactive intestinal polypeptide: DAG. diacylglycerol: $\mathbf{I P}_{\mathbf{3}}$. inositol 1.4.5-trisphosphate: GTP $\{$ S $]$. guanosine $5^{\prime}$-| $\gamma$-thio]triphosphate; TPA, 12-O-tetradecanoylpherbol 13-acetate; SLO. streptolysin O; LDH. lactate dehydrogenase.

Correspondence: R.C. De Lisie, Department of Alatomy and Cell Biology, University of Kansas Medical Center. $39^{\text {th }}$ and Rainbow Boulevard, Kansas City, KS 66103. U.S.A. protein kinase A [2]. Intact cells exhibit synergistic stimulation by DAG-, $\mathrm{Ca}^{2+}$ - and cAMP-mediated pathways [2.3]. It is difficult, however, in intact cells to investigate the interactions between these pathways because the concentration of cytosolic $\mathrm{Ca}^{2+}$ is regulated by the cell and some of the putative intracellular mediators and pharmacologic agents of interest are not permeable to the plasma membrane.

Recently, we developed a permeabilized cell system for pancreatic acini using the bacterial toxin streptolysin $O$ (SLO) [4]. Following permeabilication, amylase secretion was stimulated by submicromolar free $\mathrm{Ca}^{2+}$. and this $\mathrm{Ca}^{2+}$-stimulated amylase secretion was enhanced by the nonhydrolyzable GTP analogue guanosine $5^{\prime}-[\gamma$-thio|triphosphate $(\mathrm{GTP}\{\gamma \mathrm{S}])$ or the phorbol ester 12-O-tetradecanoylphorbol 13-acetate (TPA). In those studies, carried out at $37^{\circ} \mathrm{C}$, all regulated secretion took place in the first $10 \mathrm{~min}$ and it was difficult to accurately determine the effects of different stimuli on rates of secretion. In the present work, therefore, we evaiuated the effects of lower temperatures on the time-course and extent of amylase release. In addition, 
we inves'igated the effects of cAMP on amylase secretion from pcrmeabilized acini and the interactions between $\left(A M P, \mathrm{Ca}^{2+}, \mathrm{TPA}\right.$ and GTP[$\left.\gamma \mathrm{S}\right]$.

\section{Materials and Methods}

Chemicals. Streptolysin O (SLO) was purchased from Wel!rome Diagnostics (Greenville, NC); guannsine 5 . i $\gamma$-thio]? riphosphate (GTP[ $\gamma \mathrm{S}])$ and 3-isobutyi-1-methyl xanthine (IBMX) from Calbiochem Corpo.ation (La Jolla, CA); cyclic adenosine-3' 5'-m 'nophosrhäte (cAMP) from Boehringer Mannheim Biochemicits (Indianapolis, IN); chromatographically purified ccllagenase from Worthington Biocnemical Corpuration (Fiechold, NJ); bovine serum albumin (fraction V) from ICN Immunobiologicals (Lisle, IL): and minimal essential amino acids from GIBCO (Grand Island. NY). All other chemicals weic obtained from Sigma Chemicals (St. Louis, MO).

Preparation of isolated acini. Pancreatic acini were preparec by the modified methor of W'illiams et al. [5.6] from 19 to $21 \mathrm{~g}$ male White Swiss mice that had been fasted overnight. Briefly, pancreatic tissue was digested by purified collagenase and dispersed into individual acini by pipetting through polypropylene pipettes of decreasing diameters. A.cini were purified by centrifugation through $4 \%$ bovine sere $m$ albumin. The isolated acini were then allowed to rerover at $37^{\circ} \mathrm{C}$ for $30 \mathrm{~min}$ in Hepes-buffered Ringer solution supplemented with $11.1 \mathrm{mM}$ glucose, minimal escential amino acids, 5 $\mathrm{mg} / \mathrm{ml}$ bovine serum albumin. $0.1 \mathrm{mg} / \mathrm{ml}$ soyheal trypsin inhibitor, and equilibrated with $100 \% \mathrm{O}_{2}$. Acini were then pelleted and resuspended in Pipes-buffered Ringer solution containing $137 \mathrm{mM} \mathrm{NaCl}, 2.7 \mathrm{mM} \mathrm{KCl}$, $20 \mathrm{mM}$ Pipes (pH 7.0), $5.6 \mathrm{mg} / \mathrm{ml}$ glucose, $1 \mathrm{mg} / \mathrm{ml}$ bovine serum albumin and $0.1 \mathrm{mg} / \mathrm{ml}$ soybean trypsin inhibitor.

Membrane permeabilization and amylase secretion. In a typical secretion experiment, $1 \mathrm{ml}$ of acini in Pipesbuffered Ringer solution were added to $1 \mathrm{ml}$ of permeabilizing buffer to obtain final concentrations of 0.4 IU/ml SLO, $5 \mathrm{mM}$ ethylene glycolbis( $\beta$-aminoethyl ether) $N, N, N^{\prime}, N^{\prime}$-tetraacetic acid (EGTA), $1 \mathrm{mM}$ adenosine $5^{\prime}$-triphusphate magnesitm salt (MgATP), I $\mathrm{mM}$ free $\mathrm{Mg}^{2+}$, and various concentrations of free $\mathrm{Ca}^{2+}$. Acini were incubated at $30^{\circ} \mathrm{C}$ for $30 \mathrm{~min}$, unless otherwise noted, and a $1 \mathrm{ml}$ aliquot from each sample was then separated from the medium by centrifugation at $10000 \times g$ for $15 \mathrm{~s}$ in an Eppendorf microcentrifuge. The supcinatant was taken for measurement of amylase and lactate dehydrogenase (LDH). Basal release is defined as the release occurring at a free $\left[\mathrm{Ca}^{2+}\right]$ of less than $10^{-9} \mathrm{M}$, in the absence of other stimulatory substances. Amylase activity was determined using procion yellow starch as a substrate [7]. LDH was measured by a colorimetric method using a commervial kit (Sigma).
Secréion of amylase or leakage of LDH is expressed as a fercentage of the total content at the beginning of the incubation.

Determination of free $\mathrm{Ca}^{2+}$ concentration. Diffeicnt free $\mathrm{Ca}^{2+}$ concentrations were obtained by altering the $\mathrm{Ca}^{2+} /$ EGTA ratio. Frec $\mathrm{Ca}^{2+}$ concentrations were determined with a computer program by taking into account the bindirg of $\mathrm{Ca}$ and $\mathrm{Mg}$ ions to FGTA and ATP [8]. In the nominally $\mathrm{Ca}^{2+}$-free buffe- containing 5 mM EGTA (ivithoul addition of $\mathrm{Ca}^{2+}$ ), the free $\mathrm{Ca}^{2+}$ colicentration was less than $10^{-9} \mathrm{M}$. The expression ' $\mathrm{pCa}$ ' is used to denote the negative logarithm of the concentration of free $\mathrm{Ca}^{2+}$.

Statistics. All determinations were carried out in duplicate or triplicate, and experiments were repeated at least three times with independent preparations of acini. except where otherwise noted. Statistical analysis was performed by analysis of variance (ANOVA) followed by Newınan-Keuls test $t$ - determine the differencis among means. $P<0.0^{5}$ was considered to be significant.

\section{Results}

Effects of temperature on the kinetics of amyiase secretion.

We have previously shown that $\mathrm{Ca}^{2+}$ stimulates amylase secretion from SLO-permeabilized acini incubated at $37^{\circ} \mathrm{C}$ with a half-maximal effect at $0.4 \mu \mathrm{M}$ and a maximal effect at $1 \mu \mathrm{M}$ free $\mathrm{Ca}^{2+}$ [4]. At this temperature $\mathrm{Ca}^{2+}$-stimulated secretion occurred primarily within the first $10 \mathrm{~min}$ of stimulation. This rapid time-course made it difficult to examine the effects of mediators which enhance $\mathrm{Ca}^{2+}$-stimulated secretion. Therefore, we evaluated the effects of temperature on amylase secretion from SLO-permeabilized acini to obtain more accurate values for differences in rates of secretion. The time-courses of amylase release were examined using medium containing $<10^{-9} \mathrm{M} \mathrm{Ca}^{2+}, 1$ $\mu \mathrm{M} \mathrm{Ca}^{2+}$ and $1 \mu \mathrm{M} \mathrm{Ca}^{2+}$ plus $30 \mu \mathrm{M} \mathrm{GTP}[\gamma \mathrm{S}]$ at 14 , 22 and $30^{\circ} \mathrm{C}$ (Fig. 1). Amylase secretion from pernieabilized acini was temperature-dependent. When incubated at $14^{\circ} \mathrm{C}, \mathrm{Ca}^{2+}$-stimulated amylase secretion after $60 \mathrm{~min}$ was only $3 \%$ of the total (Fig. 1A). There was an increase in $\mathrm{Ca}^{2+}$-stimulated amylase secretion with increasing temperature. The initial rate of secretion (the linear portion) was greater at higher temperatures (Fig. 1B and C), but the longevity of stimulated secretion was shorter as temperature increased.

The other observed effect of temperature was that GTP $\left.{ }_{\gamma} \mathrm{S}\right]$ failed to enhance $\mathrm{Ca}^{2+}$-stimulated secretion at $14^{\circ} \mathrm{C}$ (Fig. 1A), while it enhanced secretion at $22^{\circ} \mathrm{C}$ and more strongly at $30^{\circ} \mathrm{C}$ (Fig. $1 \mathrm{~B}$ and $\mathrm{C}$ ). The major effect of GTP[ $\gamma \mathrm{S}]$, at a given temperature, was to increase the longevity of secretion rather than affecting 


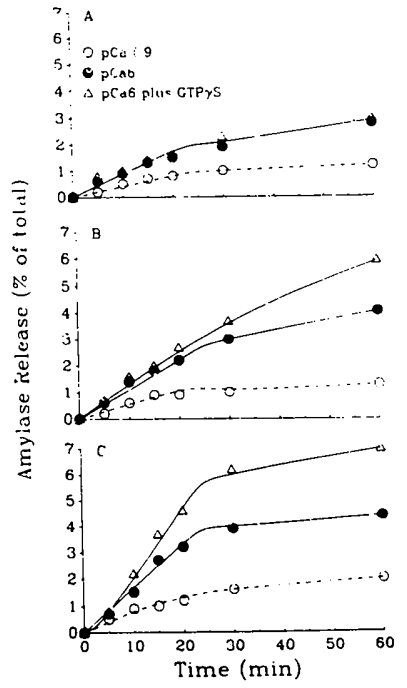

Fig. 1. Temperature-dependence of kinetics of amylase secretion "rom permeabilized acini stimulated by $\mathrm{Ca}^{2+}$ and GTP $\gamma \mathrm{Sj}$. Acini werilicubated with $0.4 \mathrm{lU} / \mathrm{ml} \mathrm{SLO}$ in $\mathrm{Ca}^{2-}$-free $(\mathrm{pCa}<9), 1 \mu \mathrm{M} \mathrm{\textrm {Ca } ^ { 2 + }}$ (pCa 6) or $1 \mu \mathrm{M} \mathrm{Ca}^{2+}$ with $30 \mu \mathrm{M} \mathrm{GiTP}[\gamma \mathrm{S}]$ ipCa 6 plus GTP $\left.\gamma \mathrm{S}\right]$ ) at $14^{\circ} \mathrm{C}$ (A). $22^{\circ} \mathrm{C}$ (B) or $30^{\circ} \mathrm{C}(\mathrm{C})$. Amylase secreted into the medium was determined at the indicated times. Data are means of duplicate determinations from a representative of two independent experinients. O. $\mathrm{pCa}<9 ;$; $\mathrm{pCa} 6$; and $\Delta, \mathrm{pCa} 6$ plus GTH $\gamma \mathrm{S}\}$.

the secretory rate. However, ai $30^{\circ} \mathrm{C}, \mathrm{GTP}[\gamma \mathrm{S}]$ also slightly increased the secretory rate (Fig. 1C).

$\mathrm{Ca}^{2+}$-stimulated amylase secretion at $30^{\circ} \mathrm{C}$ was sustained for 20-30 min and the GTPI $\gamma$ S)-enhancement was maximal and comparable to that at $37^{\circ} \mathrm{C}$ [4]. The kinetics of secretion at $30^{\circ} \mathrm{C}$ were examined in greater detail in further experiments (see below). The basal secretion was lower at $22^{\circ} \mathrm{C}$ than at $30^{\circ} \mathrm{C}$, but the GTP $[\gamma \mathrm{S}]$-enhancement of secretion was less pronounced at $22^{\circ} \mathrm{C}$. Therefore, we chose $30^{\circ} \mathrm{C}$ as the incubation temperature for the remainder of these experiments.

Leakage of the cytosolic enzyme lactate dehydrogenase (LDH) was used as a measure of cell permeabilization as previously described [4]. The rate of permeabilization at either 22 or $30^{\circ} \mathrm{C}$ was similar to that at $37^{\circ} \mathrm{C}$ [4], but was somewhat slower at $14^{\circ} \mathrm{C}$ (data not shown). A partial explanation for the decreased secretory rate at $14^{\circ} \mathrm{C}$ may be the decreased rate of permeabilization.

\section{Effects of "AMP on amylase secretion}

An additional intracellular messeng:r tha: stimulases secretion in the acinar cell is CAMP [1-3], and ts efiects on secretion irom permeabilized acini were determined in this study. Cyclic AMP in the absence of $\mathrm{Ca}^{2+}$, like $G i P[\gamma \mathrm{S}]$ and TPA [4]. had no effect on amylase secreticn (Fig. 2). In the presence of $1 \mu \mathrm{M} \mathrm{Ca}^{2+}$, cAMP enhancid anyiase secretion with a maximally effective cAMl' cc ncentration of $0.1-\bar{m} \mathrm{mM}$. Addition of the rhosphodiesterase inhibitor IBNiX, decreased the maximally effective [CAMP] to $1-10 \mu \mathrm{M}$, bu: did not further increase : 1e extent of amylase secretion (Fig. 2). IBMX alone or vith $\mathrm{Ca}^{2+}$ had no effect on amylase secreticin (data not shown). Maximail $\mathrm{Ca}^{2+}$-stimulated amylase secretion enhanced by cAMP was $43 ! \pm 23 \%$ of that in $\mathrm{Ca}^{2+}$-free medium. compared to $254 \pm 16 \%$ in the presence of $1 \mu \mathrm{M} \mathrm{Ca}^{2+}$ alone $(n=3, P<0.01$ by post-hoc Newman-Keu!r: (est).

Comparison of the kinetics of secretion enhanced by CAMP. TPA or GTP $[\gamma S]$

We studied the time-courses of amylase secretion at $30^{\circ} \mathrm{C}$ stimulated by $1 \mu \mathrm{M} \mathrm{Ca}^{2+}$, and by $1 \mu \mathrm{M} \mathrm{Ca}^{2+}$ plus cAMP $(100 \mu \mathrm{M})$, TPA $(1 \mu \mathrm{M})$ or GTP $\gamma \mathrm{S}](30 \mu \mathrm{M})$ (Fig. 3). These experiments were similar to those in Fig. 1, except that the maximum time used was $30 \mathrm{~min}$. with more time points taken in the early phase of secretion. The more detailed time-courses allowed more accurate evaluation of secretory rates when calcium was supplemented by other intracellular mediators. All three compounds enhanced $\mathrm{Ca}^{2+}$-stimulated secretion to similar extents (Fig. 3 A-C). The inajor effect of cAMP and TPA was that the lengevity of secretion was prolonged in their presence, while the initial rate of secretion seemed to be relatively unaffected. GTP[ $\gamma$ S] increased the longevity of the secretory response and aiso slightly

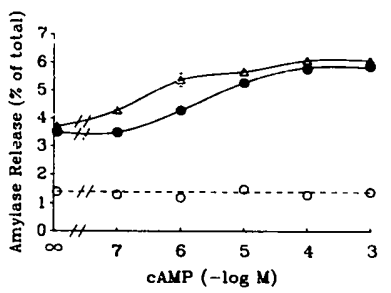

Fig. 2. Effects of cAMP on amylase secretion from permeabilized acini. Acini were incubated for $30 \mathrm{~min}$ at $30^{\circ} \mathrm{C}$ with $0.41 \mathrm{U} / \mathrm{ml} \mathrm{SLO}$ in $\mathrm{Ca}^{2+}$-free $(\mathrm{pCa}<9)$ or $1 \mu \mathrm{M} \mathrm{Ca}^{2+}\left(\mathrm{pCa}^{6}\right)$ plus the indicated cuncentrations of CAMP, with or without $0.1 \mathrm{mM}$ IBMX. Data are means \pm S.E.M. from three independent experiments. Error bars not shown are smaller than the symbols. $\mathrm{O}, \mathrm{pCa}<9 ; \bullet, \mathrm{pCa} 6$; and $\triangle$. pCa 6 plus IBMX. 


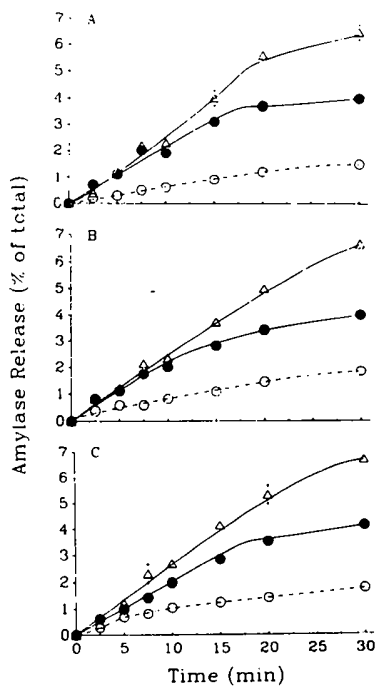

Fig. 3. Kinetics of amylase secretion from permeabilized acini stimulated by $\mathrm{Ca}^{2+}$ plus CAMP, TPA or GTP $\gamma \mathrm{S}$ ]. Acini were incubated at $30^{\circ} \mathrm{C}$ for the indicated times with $0.4 \mathrm{IU} / \mathrm{ml} \mathrm{SLO}$ in $\mathrm{Ca}^{2+}$-free (pCa<9). $1 \mu \mathrm{M} \mathrm{Ca}^{2+}$ (pCa 6 ) or $1 \mu \mathrm{M} \mathrm{Ca}^{2+}$ plus $100 \mu \mathrm{M}$ cAMP plus $0.1 \mathrm{mM}$ IBMX ( $\mathrm{PCa} 6$ plus $\mathrm{CAMP}$ ), $1 \mu \mathrm{M}$ TPA ( $\mathrm{PCa} 6$ plus TPA) of $30 \mu \mathrm{M}$ GTP $\gamma \mathrm{S}$ ] (pCa 6 plus GTM $\gamma \mathrm{S}$ ). Data are means \pm S.E.M. from three independent experiments. Error bars not shown are smaller than the symbols. O. $\mathrm{pCa}<9:-\mathrm{pCa} 6$; and $\triangle . \mathrm{pCa} 6$ plus (A) CAMP, (B) TPA and (C) CTP $Y \gamma$ S].

increased the rate of secretion (Fig. 3C). These data suggest that $\mathrm{Ca}^{2+}$ is important in the iritiation of amylase secretion, and the other intracellular mediators act to sustain secretion.

\section{Interactions between $\mathrm{Ca}^{2+}, \mathrm{CAMP}, T P A$ and $\left.G T P / \gamma S\right]$}

It is known that different intracellular mediators have syergistic effects in intact acinar cells [1-3]. The permeabilized cell provides a situation where the concentrations of such intracellular mediators can be precisely controlied and membrane-imperıneant compounds can be used. The interactions between maximaily-stimulatory concentrations [3] of $\mathrm{Ca}^{2+}$, cAMP, TPA, and GTP $\gamma$ S] were studied (Fig. 4). To evaluate levels of secretion stimulated by the different combinations of agents, the values were compared to the $\mathrm{pCa}<9$ alone (basal) or pCa 6 alone values. This was done, rather than a comparison of each $\mathrm{pCa}<9$ to $\mathrm{pCa} 6$ value pairwise. because some combinations of agents stimulatec calcium-independent secretion (see below). A.s noted above. cAMP. TPA and GTP $[\gamma$ S $]$ individually enhanced $\mathrm{Ca}^{2+}$-stimulated amylase secretion to similar extents (Figs. 3 and 4). Combinations of these three agents in the presence of $1 \mu \mathrm{M} \mathrm{Ca}^{2+}$ yielded values for secretion that amounted to levels of secretion equal to the sums of the individual enhancements. The enhancement of $\mathrm{Ca}^{2+}$-stimulated amylase secretion by cAMP plus TPA was $106 \pm 6 \%$; by cAMP plus GTP $\gamma \mathrm{S}]$ was $90 \pm 4 \%$; and by TPA plus GTP $\gamma$ S] was $92 \pm 3 \%$ of the respective sums of the enhancements observed with two of the compounds individually (Fig. 4). The enhancement of $\mathrm{Ca}^{2+}$-stimulated amylase secretion by all three compounds was $97 \pm 4 \%$ of the sum of the enhancements observed with each compound individually.

In $\mathrm{Ca}^{2+}$-free buffer, cAMP, TPA and GTP[ $\left.\gamma \mathrm{S}\right]$ had no effect on amylase secretion individually. With com* binations of two compounds. only TPA plus GTP $\gamma \mathrm{S}]$ stimulated $\mathrm{Ca}^{2+}$-independent amylase secretion. which w'as $187 \pm 38 \%$ of basal (Fig. 4). The combination of cAMP plus TPA plus GTP $\gamma$ S ], demonstrated $\mathrm{Ca}^{2+}$-independent secretion to a greater extent, which was $329 \pm 30 \%$ of basal. The enhancement of secretion due to the additional presence of calcium with all three agents is of the same magnitude as the enhancement observed in the presence of calcium and any pair of agents. Thus, the higher level of secretion with all three agents plus calcium is not due to a novel interaction of calcium with the combination of the three agents. but

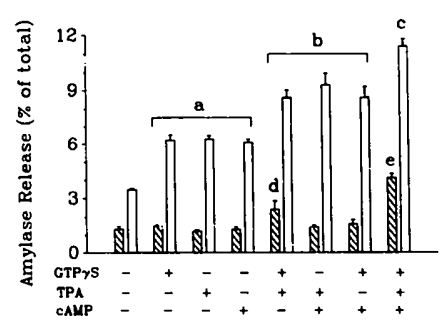

Fig. 4. Combined effects of cAMP. TPA. GTP $[\gamma \mathrm{S}]$ and $\mathrm{Ca}^{2+}$ on amylase secretion from permeabilized acini. Acini were incubated for $30 \mathrm{~min}$ at $30^{\circ} \mathrm{C}$ with $0.4 \mathrm{lU} / \mathrm{ml}$ SLO in $\mathrm{Ca}^{2+}$ - free buffer (pCa<9) or $1 \mu \mathrm{M} \mathrm{Ca}^{2+}$ buffer containing the indicated agents: GTP $[\gamma \mathrm{S}]$ (30 $\mu M)$. TPA $(1 \mu M)$ or CAMP $(100 \mu M$ cAMP $+0.1 \mathrm{mM}$ IBMX). Data are means \pm S.E.M. from three independen: experiments except for pCa $<9$ plus GTP $\mid \gamma S$ ] plus TPA. where six independent experiments were performed. Statistical analysis by analysis of variance and posthoc Newm:n-Keuls: (a) All values at pCa 6 were greater than at $\mathrm{pCa}$ 6 in the absence of the second agent. $P<0.01$. (b) All values at pCa 6 were greater than the corresponding values marked (a), $P<0.01$. (c) Value was greater tha. all pci' 6 values marked (b), $P<0.01$. (d) Value greater all than $p C a<9$ values except (e). $P<0.01$. (e) Value greater than (d). $P<0.01$. St:iped bars. $\mathrm{PCa}<9$ : and open bars. $\mathrm{pCa} 6$. 


\section{TABLE. I}

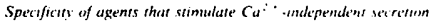

Acini were incubated with $0.41 \mathrm{U} / \mathrm{ml}$ SLO at $30^{\circ} \mathrm{C}$ ior $30 \mathrm{mIn}$ with $\mathrm{Ca}^{2}{ }^{*}$-free medium ( $\mathrm{pC} u<9$ ) contaning the indicated agents: $4 . \mathrm{MP}$ $(100 \mu \mathrm{M}$ cAMP plus $0.1 \mathrm{mM}$ JBMX), GTP $\gamma \mathrm{S})(30 \mu \mathrm{M})$. TPA $(1 \mu \mathrm{M})$ 4a-phorbol ( $1 \mu \mathrm{M} 4 \alpha$-phorhal 12.13-didecinnoate). (GDP[ $\beta \mathrm{S}](30 \mu \mathrm{M}$ guanosine 5 - $-(\beta$-thioldiphosphate). AMP (100) $\mu .1$ udenovine ?' monophosphate). Data are neans \pm S.E.M. frum three independen experiments. Statistical analysis by ANOVA and pout-hoe NewmanKeuls. N.S., not significant compared io corresp'nding value in the absence of the analogue.

\begin{tabular}{|c|c|c|}
\hline & $\begin{array}{l}\text { Amylise } \\
\text { secretion } \\
\text { ('s of (wotal) }\end{array}$ & Significance \\
\hline $\begin{array}{l}\mathrm{pCa}<9 \\
\text { plus cAMP + TPA + GTP }[\gamma \mathrm{S}]\end{array}$ & $\begin{array}{l}1.37 \pm 0.12 \\
4.37 \pm 0.07\end{array}$ & $P<0.05$ \\
\hline $\begin{array}{l}\text { plus :AMP + GTP }\{\gamma \mathrm{S}] \\
\text { plus cAMP + GTP } \gamma \text { S] }+4 a \text {-rhoshol }\end{array}$ & $\begin{array}{l}1.53 \pm 0.09 \\
1.67 \pm 0.07\end{array}$ & NSS \\
\hline $\begin{array}{l}\text { plus cAMP + TPA } \\
\text { plus cAMP + TPA + GDP } \beta S \mid\end{array}$ & $\begin{array}{l}1.33 \pm 0.03 \\
1.23 \pm 0.03\end{array}$ & NS \\
\hline $\begin{array}{l}\text { plus TPA + GTPYYS] } \\
\text { plus TPA + GTP }[\gamma S]+A M P\end{array}$ & $\begin{array}{l}2.60 \pm 0.06 \\
2.53 \pm 0.09\end{array}$ & NS. \\
\hline
\end{tabular}

rather to the calcium-independent interaction of CAMP. TPA and GTP $[\gamma$ S and the same degree of calcium-enhancement of secretion seen with pairs of the agents. $\mathrm{Ca}^{2+}$-independent amylase secretion was not observed when each of the compounds was individually replaced by chemically similar, inactive analogs (Table 1). demonstrating the specificity of each agent.

\section{$A T P$ dependence of amylase secretion stimulated by the different agents}

In intact acinar cells. metabolic inhibitors block amylase secretion [9.10]. To study whether secretion stimulated by interactions between the different intracellular mediators was ATP-dependent. acini were treated with metabolic inhibitors $(10 \mu \mathrm{M}$ antimycin $\mathrm{A}$, 0 $\mathrm{mM}$ 2-deoxyglucose and $0.5 \mathrm{mM}$ 1.2-dinitrophenol) and ATP was omitted from the medium. Addition of metabolic inhibitors had no effect on basal amylase secretion $(\mathrm{pCa}<9)$. Metabolic inhibitors decreased $1 \mu \mathrm{M} \mathrm{Ca}^{2+}$. stimulated secretion by $46 \pm 8 \%$ (Fig. 5). The enhancements of $\mathrm{Ca}^{2+}$-stimulated secretion by cAMP. TPA or GTP $[\gamma \mathrm{S}]$, however, were completely abolished by metabolic inhibitors. Similarly. $\mathrm{Ca}^{2+}$-independent amylase secretion stimulated by combined cAMP. GTP $[\gamma S]$ and TPA was inhibited by $75 \pm 9 \%$. These data suggest that in permeabilized pancreatic acinar cells. $\mathrm{Ca}^{2+}$-dependent amylase secretion is partially ATP-dependent. but the enhancernents by GTP $[\gamma \mathrm{S}]$. TPA or CAMP are absolutely ATP-dependent. The failure of metabolic inhibition to fully block secretion stimulated in the absence of $\mathrm{Ca}^{2}+$ by cAMP plus TPA plus GTP $[\gamma \mathrm{S}]$ suggests that the interaction of these

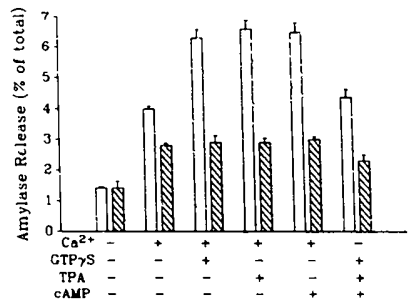

Fig. 5 . Effects of ATP depistion on amylase sectetion from permea ilaed acini. tuni were pretreated with metabolic inhibitors $(10 \mu \mathrm{M}$ anumycin $+1.6 \mathrm{mM} 2$-deoxyglucose and $0.5 \mathrm{mM} \mathrm{1.2-dinitrophenol)}$ for $3 \mathrm{~min}$ hefore permeabilization. and ATP was omitted from the incuhation medium. Acini were permeabilized with $0.4 \mathrm{IU} / \mathrm{ml}$ SLO at $30^{\circ} \mathrm{C}$ for $30 \mathrm{man}$ in $\mathrm{Ca}^{2}$-free $(\mathrm{pCa}<9)$, or $1 \mu \mathrm{M} \mathrm{Ca}{ }^{2}$ buffer containing the indicited agents with or without the same concentranons of metabolic inhibitors and without or with $1 \mathrm{mM}$ ATP. (CAMP:

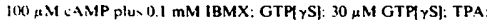
( $\mu . M$ TP.A ). Data dre means \pm S.E.M. from three independent experiments, Open hars, control: and striped hars, metabolic inhibitors.

mediators also stimulates the ATP-independent pathway to some extent.

\section{Discussion}

In the current work we examined the effects of temperature on the kinetics of secretion from steptolysin $O$ permeabilized pancreatic acini and the interactions between the three major intracellular messenger pathways $\left(\mathrm{Ca}^{2+}, \mathrm{DAG}\right.$ and $\left.\mathrm{cAMP}\right)$ and the G-protein modulator. GTP $y$ S ]. Secretion was found to be temperature-dependent in two respects. In addition to slowing the rate of $\mathrm{Ca}^{2+}$-stimulated secretion. lower temperatures also decreased or abolished the enhancement of secretion by GTP $\gamma \mathrm{S}$ ] seen at 37 or $30^{\circ} \mathrm{C}$. At $30^{\circ} \mathrm{C}$. the longevity of secretion is more than 2-times that at $37^{\circ} \mathrm{C}$ [4] and the enhancement of $\mathrm{Ca}^{2+}$ stimulated secretion by other intracellular mediators is about 2 -fold over $\mathrm{Ca}^{2+}$ alone, similar to that observed at $37^{\circ} \mathrm{C}[4]$.

The kinetics of secretion at $30^{\circ} \mathrm{C}$ showed that enhancement of $\mathrm{Ca}^{2+}$-stimulated secretion by cAMP or TPA was due to increasing the longevity of secretion. rather than an obvious change in the initial rate of secretion. With GTP $[\gamma$ S] there was also a small increase in the secretory rate in addition to increased longevity of the secretory response. If $\mathrm{GTP}[\gamma \mathrm{S}]$ is directly stimulating exocytosis through $\mathrm{G}_{\mathrm{c}}$, as postulated in Ref. 19. it may be expected to act more rapidly than agents which have their effects indirectly such as cAMP which activates cAMP-dependent protein kinase. 
In a recent study, using perifused electrically permeabilized islet cells. the effect of cAMP and phorbol ester on $\mathrm{Ca}^{2+}$-stimulated insulin secretion was reported to be an increase in the duration of the secretory response [11], similar to what we observed. Since secretory responsiveness is rapidly lost from unstimulated SLO-permeabilized acini [4j. our data suggest that activation of the various pathways immobilizes, and thus preserves, some activity that is soluble in the restino cell. It has been demonstrated that permeabilized cells do lose cytosolic components necessary for exor $j_{\text {tosis }}[12,13]$. Alternatively, it may be that the drtivated state can persist even after the effector (e.g., cAMP-dependent protein kinase or protein kinase C) tas diffused cut of the permeabilized cell and thus sustain $\mathrm{Ca}^{2+}$-stimulated secretion. We cannot at this time distinguish between these two possibilities.

The effectiveness of cAMP to stimulate amylase secretion from permeabilized pancreatic acini has been examined in two previous studies. In one of these studies, rat pancreatic acinar cells were perineabilized by electric field discharge [14], and little effect of cAMP on $\mathrm{Ca}^{2+}$-stimulated amylase release was observed. In the other study, rat acini were permeabilized with saponin [15], and cAMP was found to about double protein secretion stimulated by $100 \mu \mathrm{M} \mathrm{Ca}^{2+}$. Our results, using streptolysin $O$ permeabilized mouse acini and lower concentrations of $\mathrm{Ca}^{2+}$, agree with the latter study, in that we found cAMP enhanced $\mathrm{Ca}^{2+}$-stimulated secretion about 2-fold over $\mathrm{Ca}^{2+}$ alone.

We had previously noted that the enhancements of $\mathrm{Ca}^{2+}$-stimulated secretion by TPA and GTP $[\gamma \mathrm{S}]$ were additive, suggesting that the pathways mediated by these two agents were distinct from each other [4]. In the present work, we studied the effects of the other major intracellular messenger, cAMP, in various combinations with the other intracellular mediatcrs. Like TPA and GTP $[\gamma \mathrm{S}]$, cAMP enhanced $\mathrm{Ca}^{2+}$-stimulated secretion. Furthermore, enhancement of $\mathrm{Ca}^{2+}$-stimulated secretion by cAMP was additive with either TPA or GTP[ $\gamma \mathrm{S}]$ as well as the combination of both. These data demonstrate that the three pathways mediated by cAMP, TPA and GTP $[\gamma \mathrm{S}]$ are parallel and probably converge at a distal step in the exocytotic process. These different pathways also interact since they sitmulate $\mathrm{Ca}^{2+}$-indcpendent secretion in certain combinations, but not individually (see below). The data also suggest that each pathway activated to its full extent does not stimulate the maximum secretory activity possible. Thus, the capacity of the exocytotic machinery is greater than any single pathway can activate. This type of arrangement provides for a graded secretory response in situ, where combinations of hormones and neurotransmitters differentially stimulate a $\left[\mathrm{Ca}^{2+}\right]_{i}$ increase, DAG production and cAMP generation [1-3].
In intact cells metabolic activity is necessary for secretion [9]. However, in permeabilized cells, metabolism (or the addition of exogenous ATP) is not so clearly required for secretion [16-19]. In our system, we found that $\mathrm{Ca}^{2+}$-stimulated secretion was partially ATP-dependent, while about $50 \%$ secretory response remained with metabolically poisoned cells in ATP-free medium. By contrast, the enhancements of secretion by cAMP, TPA or GTP $\gamma$ S $]$ were fully ATP-dependent. This is expected for cAMP and TPA, which are believed to act by stimulation of protein kinase $A$ (cAMP-dependent protein kinase) and protein kinase $C$. respectively. Why the GTP $[\gamma \mathrm{S}]$-induced enhancement should be ATP-dependent awaits the discovery of the mechanism by which $G$ proteins act in exocytosis (see Ref. 19 for a current review of G-proteins in exocytosis). The failure of netabolic inhibition to fully block $\mathrm{Ca}^{2+}$-independent secretion stimulated by the combination of CAMP. TPA and GTP $[\gamma \mathrm{S}]$ is not clear at this time, but this result suggests that the interaction of these three intracellular mediators stimulates both ATP-dependent and ATP-independent mechanisms of exocytosis.

Of the intracellular messengers we used, only $\mathrm{Ca}^{2+}$ was able to stimulate amylase secretion by itself. However, in $\mathrm{Ca}^{2+}$-free medium, the combination of TPA and $G T P[\gamma \mathrm{S}]$ significantly stimulated secretion, which was further enhanced by the additional presence of cAMP. This finding of calcium-independent secretion in permeabilized cells has implications for the biochemical mechanism of exocytosis. It had been widely believed from studies on intact cells that exocytosis was $\mathrm{Ca}^{2+}$. dependent (Refs. 2, 10 and 20: for a current review the role of $\mathrm{Ca}^{2+}$ in exocytosis see Ref. 21). In the permeabilized cell, the free $\left[\mathrm{Ca}^{2+}\right]$ can easily be lowered to less than $1 \mathrm{nM}$, which is, physiologically speaking, $\mathrm{Ca}^{2+}$ free. The fact that a combination of intracellular messengers can elicit secretion in $\mathrm{Ca}^{2+}$-free medium demonstrates that the exocytotic mechanism in the pancreatic acinar cell under certain conditions is not a totally $\mathrm{Ca}^{2+}$-dependent process. Calcium-independent sec: :tion has been reported in a variety of secretory cells studied by permeabilization techniques. For example. exocytosis can be stimulated without $\mathrm{Ca}^{2+}$ by cAMP in parotid acini [22], by phorboi ester plus G'TP $\gamma \mathrm{S}$ ] in HL60 promyelocytic cells [23], and by TPA in $\mathrm{GH}_{3}$ pituitary cells [24]. The actual exocytotic mechanism remains unknown, but it is clear that exocytosis inay be activated and modulated by multiple pathways in a variety of cell types.

\section{Acknowledgments}

This work was supported by NIH grants DK 41122 (J.A.W.) and GM 41388 (R.C.D.), and a Lilly Internalional Feilowship (M.K.). 


\section{References}

1 Hooman. S.R. and Williams. J.A. (1987) in Physiology of the Gastroitnestinal Tract (Johnson. L.R.. ed.). 2nd Edn.. pp. 11291146. Raven Press. New York.

2 Schulz. I. and Stolze. H.H. (1980) Annu. Rev. Phyviol. 42. 127-156.

3 Burnham, D.B. McChesney, D.J., Thurston. K.C. and Williams. J.A. (1984) J. Physiol. (Lorid.) 349, 475-482.

4 Kitagawa. M., Williams. J.A. and De Lisle. R.C. (1990) Am. J. Physiol. 259. G157-G164.

5 Williams. J.A., Korc. M. and Dormer. R.L. (1978) Am. J. Physiol 235. ES17-ES24.

6 De Lisle, R.C. and Williams, J.A. (1987) Am, J. Physiol. 253. G711-G719.

7 Jung. D.H. (1980) Clin. Chim. Acta 100, 7-11.

8 Martell. A.E. and Smith. R.M. (1974) Critical Stability Constants. Vol. 1. Plenum Press, New York.

9 Jamieson, J.D. and Palade, G.E. (1971) J. Cell Biol. 48, 503-522.

10 Williams, J.A. and Lee, M. (1974) Biochem. Biophys. Res. Commun. 60. 542-548.

11 Jones. P.M.. Persaud. S.J. and Howell. S _. (1989) Biochem. Biophys. Res. Commun. 162. 998-1003.
12 Martin. T.F.J. and Walent. J.H. (1989) J. Biol. Chem. 264.10299. 10308 .

13 Koffer. A and Gomperts, B.D. (1989) J. Cell Sci. 94, 585-591

14 Knight. D.E and Xoh, E. (1984) Cell Calcium 5, 401-418.

15 Kimura. T., Imamura, K., Eckhardt, L. and Schulz. I. (1986) Am. J. Phvisiol. 250. G698-G708.

16 Holz. R.W.. Bittner, M.A., Peppers, S.C. Senter. R.A. and Fherhard. D.A. (1989) J. Binl. Chem. 264, 5412-5419.

17 Howell. T.W. and Gomperts. B.D. (1987) Biochim. Biophys. Acta 927. 177-183.

18 Stuchficld. J. and Cockcroft. S. (1988) Biochem. J. 250, 375-382.

19 Gomperts, B.D. (1990) Annu. Rev. Physiol. 52, 591-606.

20 Baker, P.F. and Knight. D.E. (1981) Phil. Trans. R. Soc. Lond. B 296, 83-10?

$\therefore 1$ Penner. K. and Neher, E. (1988) J. Exp. Biol. 139. 329-345.

22 「akuma, T. and Ichida. T. (1988) J. Biochem. 103, 95-98.

23 Stutchfietd, J. and Cockcroft, S. (1988) Biochem. J. 250, $375-382$.

24 Ronning. S.A. and Martin. T.F. (1985) Bichem. Biophys. Rex. Commun. 130. 524-532. 